\title{
Tax Evasion in Cameroon: Causes and Remedies
}

\author{
Samuel Tanjeh Mukah ${ }^{1} \quad$ Michael Forzeh Fossung ${ }^{2}$ \\ 1.Senior Lecturer of Accounting and Finance, Faculty of Economics and Management Sciences, \\ University of Bamenda, Cameroon. \\ 2.Senior Lecturer of Accounting and Finance, Faculty of Social and Management Sciences, \\ University of Buea, Cameroon.
}

\begin{abstract}
The Cameroon government imposes charges on citizens and corporate bodies called taxes in a bid to raise funds to pay for public services or facilities. It also uses taxation in the redistribution of wealth, and in encouraging or discouraging the consumption of some goods and services. In a circular No. 001/C/MINFI of $2^{\text {nd }}$ January 2018 by the Ministry of Finance of Cameroon, stringent measures were undertaken regarding the detection of "concealed" income or tax evasion, a phenomenon that stifles government efforts in realising its tax objectives. As a consequence, this study sought to investigate the causes of tax evasion in Cameroon and propose remedies. Data was collected through a survey carried out in the cities of Douala, Bafoussam and Bamenda, and analysed using the Ordinary Least Square (OLS) estimation technique. The empirical results were of positive and statistical significance and revealed that tax evasion in Cameroon is caused by high tax rates, complex and opaque tax laws, inefficient and corrupt tax inspectors, low income of taxpayers, evasion benefits outweighing detection penalties, poor perception of the judicial system and dissatisfaction with the quality and magnitude of public services and goods. Remedies proposed were that there should be a reduction and clear justification of tax rates, simplification of tax laws and effective education of taxpayers, creation of a more conducive business environment to boost business income, raise tax penalties, identify and deal with inefficient and corrupt tax authorities, liberate the judiciary to be truly independent to show proof of fairness and transparency in the treatment of tax matters and politicians being transparent and accountable for their decisions and use of public money. Tax ethics should be introduced and enforced in schools in order to build a culture of tax compliance in citizens, assiduity and honesty in tax authorities, and transparency and accountability in politicians and everyone in public offices.
\end{abstract}

Keywords: Tax compliance, tax evasion, tax ethics, Cameroon.

DOI: $10.7176 /$ RJFA/10-14-08

Publication date:July $31^{\text {st }} 2019$

\section{Introduction}

Taxation denotes the practice of governments imposing charges on citizens and corporate bodies in a bid to raise funds to pay for public services or facilities such as national defence and security, public health, road construction and maintenance, courts, schools, libraries, and parks. A government may also use taxation in the redistribution of wealth. It is one of the most acclaimed discussions during top-level political debates in both developed and developing countries. Through taxation, governments could encourage or discourage the consumption of any good or service. Every taxpayer in Cameroon is required to fill and submit a tax return to the taxation office in the taxation area of concern. The exception to this are taxpayers who are fully taxed at source such as civil servants, employees of public corporations and public establishments, regional and local authorities.

Tanzi and Zee, (2001) describe taxation as the only practical means of raising revenue to finance government spending on the goods and services that most people demand. To set up an efficient and fair tax system for developing countries has ever been overwhelmed with formidable challenges. Some of the challenges stem from the fact that most workers are typically employed in agriculture or in small, informal businesses without accurate records, thus making income and consumer tax calculations unreliable. According to the Vito and Zee (2001), an ideal tax system in a country like Cameroon should be one ttthat can raise essential revenue without excessive government borrowing, and should do so without discouraging economic activity and without deviating too much from tax systems in other countries.

A sound taxation system leads to a strong, sustained and inclusive economic development when the revenue funds public expenditure on physical, social and administrative domain enabling businesses to start or expand. A sound tax or revenue system is also pivotal in supporting a strong citizen-state relationship that culminates effective, accountable and stable governments (Carnahan, 2015).

One of the greatest challenges faced by the Cameroon tax system today is the problem of tax evasion, a phenomenon which occurs when efforts are made by individuals, firm's trusts and various other entities to avoid paying taxes by illegal and unfair means. Usually, this takes place when taxpayers deliberately hide their incomes from the tax authorities in order to reduce their tax liability, Devarajappa (2017). Tax evasion involves the deliberate act of noncompliance to tax legislation and the disregard of tax payments from the citizens, Drogalas et al. (2018). Withholding information regarding one's income in order to pay less tax deprives the government of 
the much-needed income to provide public goods and services.

The Organisation for Economic Cooperation and Development (OECD) describes the concept of tax evasion as an illegal arrangement where tax liabilities are either hidden or ignored. That is, the taxpayer pays less tax than he/she is legally obliged to pay by concealing income or information from the tax authorities.. Given the importance of tax revenue in the provision of public services, a country increasingly plagued by tax evasion is likely to exhibit a low productive investment mix, hence low economic growth as the public-run enterprises would be negatively affected (Dalu et al. 2012).

Tax evasion is criminal and has a lot of negative social and economic consequences. It deprives the government of substantial revenue and also leads to uneven distribution of tax burdens. In order to bridge the gap, the government may be tempted to raise taxes which in turn slow down economic growth and place extra load on loyal taxpayers.

In Cameroon, the public sector accounting and finance is managed by the Ministry of Finance (MINFI). It ensures the preparation, approval and implementation of the government budgets, and the preparation of the public sector financial reports for audit and publication (Mukah, 2015). In light of this, MINFI undertakes strict measures regarding the detection of "concealed" income. In a circular No. 001/C/MINFI of $2^{\text {nd }}$ January 2018, the Minister of Finance issued instructions relating to the execution of finance laws, the monitoring and control of the execution of the budget of the State, public corporations and public establishments, regional and local authorities and other subsidised bodies, for the 2018 financial year. Conscious of the fact that tax evasion has become a common practice, the circular carried certain measures relating to the fight against tax fraud and evasion.

The circular called for an improvement in the methods of collecting tax information by providing information about persons who may be liable to pay taxes, duties or levies to tax authorities by every public or private body; encouraging the visitation of tax administration with a view to strengthening its powers of action in the fight against fraud; and a reinforcement of communication with tax authorities with regards to transfer prices of all kinds between intra-group companies. Such improved communication was to make way for better programming of tax controls based on previously identified risks (MINFI, 2018).

The circular also called for the strengthening of collaboration between the taxpayers and the customs administration so as to curb tax evasion. To attain this, one of the strategies is to present a receipt showing payment of duties at the Directorate General of Taxation before a clearance certificate for imported second-handed vehicles is issued. Also, through the external constraint procedure, internal taxes and duties owed by an importer can be subject to recovery by the Customs Revenue Collector.

Given all these worries and efforts expressed by the Ministry of Finance with regards to financial accountability and management in Cameroon, given the devastating consequences of tax evasion on the economy of Cameroon, the study sought to investigate why some taxpayers in Cameroon evade the payment of taxes and what remedies there are to curb or mitigate the situation. To attain this, the following research questions were designed:

i. What are the causes of tax evasion in Cameroon?

ii. What are the remedies to tax evasion in Cameroon?

The main objective of the paper was to investigate the causes and remedies of tax evasion in Cameroon. The specific objectives were stated as follows:

i. To investigate the causes of tax evasion in Cameroon, and

ii. To seek remedies to tax evasion in Cameroon.

The rest of the paper presents a review of related literature, the methodology applied, analysis and discussion of the results, policy implications and a conclusion.

\section{Review of Related Literature}

The concept of tax evasion denotes a deliberate omission on a tax return, not filing a tax return or non-payment of all taxes due. In tax evasion, the taxpayer deliberately and illegally escapes payment of taxes through fraudulent practices such as underestimation of taxable income, exaggeration of expenses and losses, nondisclosure of material facts and non-payment of taxes (Kalpana, 2016). Tax evasion embroils the deliberate act of not complying with tax legislation and the disregard of tax payments from the citizens (Drogalas et al. 2018).

There are legal and moral implications when information regarding a tax payer's income is witheld, or when there is a dishonest submission of a tax return involving undeclared income (McGee and Rossi, 2006). The concept of tax evasion according to the Organisation for Economic Cooperation and Development - OECD (2017) is commonly used to describe unlawful arrangements where tax obligations are either concealed or ignored, thus making the taxpayer to pay less tax than he is legally obliged to pay.

Martinez-Vazquez and McNab (2003) argue that the existence of a 'social norm' of compliance and an effective public service-oriented tax administration are crucial in determining tax evasion. Every taxpayer expects a fair service from the government for taxes paid. The more the service received the more tax compliance. Contrariwise, in a country where the government wastes the taxpayers' money as a result of corruption and other 
inefficiencies, tax evasion is bound to prevail. According to Dalu, Maposa, Pabwaungana, and Dalu (2012) taxpayers aim at minimising their financial position and will continue to evade taxes as long as the benefits from delinquency outweigh the risk of detection and penalty. The application of severe penalties may not be a solution given that many tax evasions are not detected due to taxpayers' interference with tax authority through corruption and bribery.

Tax avoidance is another related concept. It is defined by the Oxford Dictionary of Accounting (2010) as minimising tax liabilities legally and by means of full disclosure to the tax authorities. This definition is corroborated by Gooch and Williams (2015) as the lawful arrangement or planning of one's affairs so as to reduce tax liability. Xuereb (2015) stating Lord Nolan, in the case of IRC versus Willoughby (1997), revealed that tax avoidance covers instances where the intention and policy of the lawmaker failed to anticipate and reach the transaction under consideration. This suggests that the taxpayer reduces his tax liability without suffering the economic consequences intended by the Parliament to be suffered by any taxpayer who qualifies for such a drop in tax liability (Christians, 2017).

Many at times the concepts of tax evasion and tax avoidance are erroneously used interchangeably. According to Elliffe (2011), the former UK Chancellor of the Exchequer Denis Healey once described the difference between these two concepts to be like the thickness of a prison wall. Such a quote explicitly illustrates that whereas tax avoiders are found on the outside of the prison wall, some tax evaders are incarcerated inside. This denotes that tax evasion is criminal whereas tax avoidance is not. It also portrays that tax avoidance though not a crime, may be very close to tax evasion to have a common feature like dispossession of the government of the much-needed tax revenue.

Drogala et al. (2018) advise against the use of the concepts, tax ethics and tax evasion interchangeably. According to them, tax ethics denotes the moral responsibility of the taxpayer to pay taxes. They hold the view that this moral obligation is affected by the relationship existing between the taxpayer as a citizen, and the government. Torgler and Schneider (2009) induce that where the tax ethics is low, probably as a result of a poor relationship between the taxpayers and the government, tax evasion rises. Tax ethics is affected by non-monetary inducements that motivate taxpayers as the public to comply with tax legislation as they enjoy a better relationship with the government (Olsen, Kang, and Kirchler, (2012). Although not specified, this relationship could be observed in the quality and quantity of public services and goods provided by the government to its taxpayers and citizenry.

On the other hand tax compliance is the filing of all required tax returns at the appropriate time. Such returns truthfully report tax liability in accordance with the appropriate tax laws at the time of filing the returns, Roth et al. (1989). Consequently, tax compliance comprises reporting income, and paying all taxes in accordance with the applicable laws, regulations, and court decisions, Alm (1991). Franzoni (2000) expounds further to say that tax compliance characteristically means true reporting of the tax base, accurate calculation of the liability, timely filing of the returns and payment of the amounts outstanding. The General tax code in Cameroon provides that every registered business in Cameroon files in its tax returns by March 15. When this is not done, tax noncompliance is said to set in.

Benefit theory is one of the theories closely associated with tax accounting in general and tax evasion in particular. According to Merriam Webster Dictionary, benefit theory of taxation requires that taxes be considered as payments for services rendered by the state to the taxpayers and so should be proportioned. This infers that the more benefits a person derives from the activities of the state, the more he should pay taxes to the government. This principle has suffered severe reproach on the grounds that it opposes the basic principle of taxation which according to Adam (1950), requires subjects of every state to contribute towards the support of the government, as nearly as possible, in proportion to their respective abilities.

Another criticism of the benefit theory stalks from the fact that most of the expenditures incurred by the state are for the general benefit of its citizens, and it is not conceivable that the benefit enjoyed by a particular individual every year can be estimated. Furthermore, if the benefit theory of taxation was really feasible, then the poor will pay heavier taxes than the rich since they benefit more from the services of the state than the rich. If the poor lose more money than the rich by way of taxes, this will be against the principle of justice and equity. The equity principle requires that every taxpayer should pay tax in proportion to his or her income. The rich should pay at a higher rate than the poor (Jhingan, 2004). Unless a tax is based on the ability of the taxpayer to pay, it cannot be considered equitable or just (Anyanfo, 1996).

The cost of service theory is closely related to the benefit theory. It requires each taxpayer to sustain the cost of any public service or good consumed. This may be applicable to goods and services such as water, electricity, communication, transportation, and postal services whose prices in relation to consumption are easy to determine. However, most expenditure incurred by the state such as the police and the army cannot easily be determined and allocated to individuals. In addition, the cost of the services rendered by the state is a direct function of the efficiency of the government. That is, if the public administrators are efficient, the cost of public goods and services too will be lower. The contrary is true, and it will be an aberration to shift the cost of inefficient public 
administrators to taxpayers.

A study carried out by Vythelingum, Soondram, and Jugurnath, (2017) to assess the tax morale among Mauritian taxpayers revealed that, tax compliance increases when the public has faith in the tax and legal systems being stable, fair and transparent and effectively fights against corruption. In a related study by Drogalas et al. (2018), tax evasion steps up when taxpayers believe that public money is not efficiently allocated by the government to its citizens. That is, when taxpayers feel discontented as a result of the way public resources are squandered, they tend to evade taxes. In this regard, they recommended a legal framework that makes politicians accountable for their decisions and the use of public money. In their opinion, such a legal framework rebuilds the trust between the government and its citizens.

In studying the causes of tax evasion and corruption in the Indian income tax system, Arora and Vanita (2010) disclosed that high tax rates, social acceptance of tax evasion, poor tax evasion detection mechanisms, low tax ethics, and corruption, constitute the main reasons why evasion thrives in India. The study furthermore revealed that the income tax authorities apart from being morally bankrupt, wielded excessive discretionary powers that led to corruption. As a remedy, they proposed the justification of tax rates, simplification of tax regulations and laws. They also encouraged an extensive application of the tax system where tax is deducted at source, and proper processing and dissemination of tax information, in a bid to step up tax compliance.

In the same light, Wadhwa and Pal (2012) in carrying out forensic accounting and fraud examination in India opined that high and multiple tax rates, corrupt and inefficient tax authorities are the principal causes of tax evasion. They proposed the reduction of tax rates, simplification of tax laws, sanitation of the tax system, and proper processing of tax information as a remedy to reinstate tax compliance.

In a study conducted in the ten regional capitals of Ghana of the factors that influence tax evasion behaviour in the country, Ameyaw and Dzaka (2016) disclosed that high tax rates, low probability of detecting tax evasion and imposing of penalty on evaders, income level fluctuations, demographic characteristics such as gender, age, race and educational level are the key factors that thwart tax compliance. As a remedy to tax noncompliance, they saw the need for governments, stakeholders and policymakers to come out with pragmatic measures such as tax rates reduction believed to enhance and boost revenue generation, hence tax net that captures many taxpayers into tax compliance. Tax rates reduction spreads the tax burden from a few loyal individuals to many more taxpayers. In the same light with Fishlow and Friedman (1994), Ameyaw and Dzaka (2016) posit that higher penalties act as a deterrent and help to improve tax compliance. They also proposed an increase in tax education of taxpayers of changes in tax legislation and a serious check on the tax system loopholes such as corruption.

According to Tanzi (1983), generally, tax rates constitute a primary determinant of tax evasion. Empirical shreds of evidence have yielded diverse results ranging from neutral effect to significantly positive and negative effect on tax evasion. Allingham and Sandmo (1972) revealed that there exists a statistically significant positive effect of tax rates to tax evasion.

\section{Methodology}

Cameroon is a Central African country on the Gulf of Guinea. According to the World Health Organisation (WHO) 2016 statistics, it has a population 23,439,000, WHO (2019). It has Douala as its economic capital and Yaounde as its political capital. The population for the study was taxpayers in Douala, Bafoussam, and Bamenda. Douala is the economic capital of Cameroon and is located on the estuaries of the Wouri River. It is the capital of Wouri Division. It harbours the main seaport of Cameroon that provides services to the Central Africa sub-Saharan region and some of the member states of the Communauté Économique des États d'Afrique Centrale (CEMAC) countries. According to Ngoran (2014), Douala city harbours some $80 \%$ of Cameroon's industries. This suggests that through taxation, the government should generate a lot of income from Douala. Bafoussam is the capital of Mifi Division and largest city of the West Region of Cameroon. After Yaounde and Douala, Bafoussam is the 3rd most business inclined city in Cameroon. Bamenda is the biggest city in the English speaking region of Cameroon. It is the capital of Mezam Division and also, the capital of the North West Region.

The research design adopted was a survey research design. A total of 500 copies of questionnaire were administered at random to taxpayers in the cities of Douala, Bafoussam and Bamenda. 351 respondents filled and returned the questionnaire giving a response rate of $70.2 \%$. The first part of the questionnaire carried the bio-data of participants comprising: gender, age, occupational status, educational level, and marital status. Respondents were asked to express their level of perception to statements regarding tax evasion at a five-scale Likert type scale rated as follows: (1) Strongly disagree, (2) Disagree, (3) Not decided, (4) Agree, (5) Strongly agree. The objective was to get the perceptions of the taxpayers on tax evasion in these cities.

From the data collected through questionnaire arithmetic means and standard deviation were used to analyse the findings. The standard deviation ensures the determination with greater accuracy the location of the values of a frequency distribution in relation to the mean. The sufficiently large sample size $(>30)$ led to the application of the central limit theorem. The central limit theorem holds that if a population is not normally distributed with an increase in sample size, the distribution of the sample mean approaches normality, Henry (1990). 
A regression model to present the relationships between the dependent variable (tax evasion in Cameroon) and explanatory variables was presented as follows:

$\mathrm{TEC}=\mathrm{f}(\mathrm{HTR}, \mathrm{COTL}, \mathrm{ICTI}$, PPS, LI, EBODP, PJS $)$, and the econometric expression is as follows:

$\mathrm{TECi}=\beta 0+\beta 1 \mathrm{HTRi}+\beta 2 \mathrm{COTLi}+\beta 3 \mathrm{ICTI}+\beta 4 \mathrm{PPSi}+\beta 5 \mathrm{LIi}+\beta 5 \mathrm{EBODPi}+\beta \mathrm{PJSi}+\lambda \mathrm{i}$

Where:

TEC $=$ tax evasion in Cameroon; HTR $=$ high tax rates; COTL $=$ complex and opaque tax laws; ICTI $=$ inefficient and corrupt tax inspectors; PPS = poor public services; $\mathrm{LI}=$ low income; EBODP $=$ evasion benefits outweigh detection penalties; PJS $=$ perception of the judicial system; $\beta 0=$ Intercept; $\beta 1, \beta 2, \beta 3, \beta 4, \beta 5$ and $\beta_{6}=$ Parameters coefficients to be estimated for the variables in the regression equation; $\lambda=$ Error or disturbance term with its assumed normality.

STATA 12.0 version was used to analyse the data. The model coefficients were estimated using the Ordinary Least Square (OLS). The apriori expectation of the estimated parameters was that $\beta 1, \beta 2, \beta 3, \beta 4, \beta 5$, and $\beta 6$ were to be greater than zero to suggest the existence of a positive functional relationship between the independent variables and tax evasion in Cameroon. The regression results of the determinants of tax evasion were estimated using the ordered logit estimation technique. In the interpretation of the coefficients, a negative value will suggest that individuals will not pay all their taxes, hence indicating the likelihood of a rise in tax evasion.

\section{Presentation and Analysis of Results}

The discussion begins with a characterisation of the determinants of tax evasion. Table 1 shows the various schemes through which tax evasion is carried out in Cameroon. They are: keeping of fake invoices and sales record, concealing profits by understating income and overstating expenses, submission of fake returns, making claims to fictitious deductions, and bribing and corrupting tax authorities.

\section{Table 1. Tax evasion schemes}

\begin{tabular}{|c|c|c|c|c|c|c|}
\hline $\begin{array}{l}\text { Taxpayers do not declare all income } \\
\text { because: }\end{array}$ & $\begin{array}{l}\text { Strongly } \\
\text { disagree }\end{array}$ & Disagree & $\begin{array}{l}\text { Not } \\
\text { decided }\end{array}$ & Agree & $\begin{array}{l}\text { Strongly } \\
\text { agree }\end{array}$ & Total \\
\hline $\begin{array}{l}\text { a) They keep fake invoices and sales } \\
\text { records. }\end{array}$ & $\begin{array}{l}88 \\
25 \%\end{array}$ & $\begin{array}{ll}56 \\
16 \%\end{array}$ & $\begin{array}{l}14 \\
4 \%\end{array}$ & $\begin{array}{l}102 \\
29 \%\end{array}$ & $\begin{array}{l}91 \\
26 \%\end{array}$ & 351 \\
\hline $\begin{array}{l}\text { b) They conceal profits by understating } \\
\text { income and overstating expenses }\end{array}$ & $\begin{array}{ll}60 \\
17 \%\end{array}$ & $\begin{array}{l}67 \\
19 \%\end{array}$ & $\begin{array}{l}24 \\
7 \%\end{array}$ & $\begin{array}{l}105 \\
30 \%\end{array}$ & $\begin{array}{l}95 \\
27 \%\end{array}$ & 351 \\
\hline c) Submission of fake returns & $\begin{array}{l}39 \\
11 \% \\
\end{array}$ & $\begin{array}{l}52 \\
15 \% \\
\end{array}$ & $\begin{array}{l}39 \\
11 \% \\
\end{array}$ & $\begin{array}{l}116 \\
33 \%\end{array}$ & $\begin{array}{l}105 \\
30 \%\end{array}$ & 351 \\
\hline $\begin{array}{l}\text { d) They make claim to fictitious } \\
\text { deductions }\end{array}$ & $\begin{array}{l}35 \\
10 \%\end{array}$ & $\begin{array}{l}74 \\
21 \%\end{array}$ & $\begin{array}{l}105 \\
30 \%\end{array}$ & $\begin{array}{l}63 \\
18 \% \\
\end{array}$ & $\begin{array}{l}74 \\
21 \%\end{array}$ & 351 \\
\hline e) They bribe and corrupt tax authorities & $\begin{array}{l}70 \\
20 \%\end{array}$ & $\begin{array}{l}45 \\
13 \%\end{array}$ & $\begin{array}{l}70 \\
20 \%\end{array}$ & $\begin{array}{l}85 \\
24 \%\end{array}$ & $\begin{array}{l}80 \\
23 \%\end{array}$ & 350 \\
\hline
\end{tabular}

\section{Source: Authors' computation}

Concerning keeping fake invoices and sales record as a way to evade tax, $25 \%$ of the respondents strongly disagreed; $16 \%$ disagreed; $4 \%$ undecided; $29 \%$ agreed and $26 \%$ strongly agreed. With regards to concealing profits by understating income and overstating expenses, $17 \%$ of the respondents strongly disagreed; $19 \%$ disagreed; $7 \%$ undecided; $30 \%$ agreed and $27 \%$ strongly agreed. With respect to submitting fake returns as a means of evading tax, $11 \%$ of the respondents strongly disagreed; $15 \%$ disagreed; $11 \%$ undecided; $33 \%$ agreed and $30 \%$ strongly agreed. Regarding making claims to fictitious deductions as a means of evading tax, $10 \%$ of the respondents strongly disagreed; $21 \%$ disagreed; $30 \%$ undecided; $18 \%$ agreed and $21 \%$ strongly agreed. With respect to bribing and corrupting tax authorities as a way of evading tax, $20 \%$ of the respondents strongly disagreed; $13 \%$ disagreed; $20 \%$ undecided; $24 \%$ agreed and $23 \%$ strongly agreed.

Appendix 1 titled determinants of tax evasion in Cameroon, presents the descriptive results. The respondents used each variable presented in the questionnaire to perceive the effect on tax evasion. Respondents gave their perceptions as strongly disagree, disagree, not decided, agree or strongly agree with each variable capturing tax evasion.

Appendix 1(a) considers the various elements of a high tax rate as a justification of tax evasion. The elements were: lack of enough money to pay all the tax; tax rate being too high compared to the income made, and many taxes to pay. Concerning lack of money to pay all the tax, $13 \%$ of the respondents strongly disagreed; $20 \%$ disagreed; $7 \%$ undecided; $29 \%$ agreed and $31 \%$ strongly agreed. With respect to very high tax rate compared to income, $5 \%$ of the respondents strongly disagreed; $11 \%$ disagreed; $6 \%$ undecided; $41 \%$ agreed and $37 \%$ strongly agreed. Regarding many taxes to pay, $17 \%$ of the respondents strongly disagreed; $8 \%$ disagreed; $11 \%$ undecided; $21 \%$ agreed and $43 \%$ strongly agreed.

Appendix 1(b) considers the complexity and opaqueness in the tax laws as a justification for tax evasion. The items considered as complex and opaque tax laws were: tax laws not understood; tax regulations being too many 
and confusing; calculation not easy to understand and copies of the tax code or law being available only to the tax inspectors. Concerning the tax laws not being understood as a justification of tax evasion, $9 \%$ of the respondents strongly disagreed; $12 \%$ disagreed; $13 \%$ undecided; 32\% agreed and 34\% strongly agreed. With respect to tax regulations being too many and confusing, $10 \%$ of the respondents strongly disagreed; $13 \%$ disagreed; $8 \%$ undecided; $33 \%$ agreed and 36\% strongly agreed. Regarding calculation not easy to understand, $4 \%$ of the respondents strongly disagreed; $6 \%$ disagreed; $1 \%$ undecided; $22 \%$ agreed and $67 \%$ strongly agreed. Concerning copies of the tax code/law being available only to the tax inspectors as justification for tax evasion, $1 \%$ of the respondents strongly disagreed; $4 \%$ disagreed; $12 \%$ not decided; $25 \%$ agreed, and $58 \%$ strongly agreed.

Appendix 1(c) shows the result of inefficient and corrupt tax inspectors (ICTI) as a reason for tax evasion. The components of inefficient and corrupt tax are: taxpayers not having trust in tax inspectors; taxpayers can easily bribe out their way; they can easily negotiate with tax agents; tax auditors/ inspectors don't question amount declared and tax agents are kind and accept pleas. $21 \%$ of the respondents strongly disagreed not having trust in tax inspectors as a justification of tax evasion; $19 \%$ disagreed; $9 \%$ undecided; $22 \%$ agreed and $29 \%$ strongly agreed. With respect to taxpayers easily bribing out their way, $16 \%$ of the respondents strongly disagreed; $20 \%$ disagreed; $24 \%$ undecided; $19 \%$ agreed and $21 \%$ strongly agreed. Regarding negotiating with tax agents easily, $17 \%$ of the respondents strongly disagreed; $22 \%$ disagreed; $5 \%$ undecided; $24 \%$ agreed and $32 \%$ strongly agreed. For tax auditors/inspectors not questioning amount declared, $32 \%$ of the respondents strongly disagreed; $20 \%$ disagreed; $13 \%$ not decided; $17 \%$ agreed; $18 \%$ strongly agreed. As concerned tax agents being kind and accepting pleas, $20 \%$ of the respondents strongly disagreed; $15 \%$ disagreed; $25 \%$ not decided; $19 \%$ agreed; $21 \%$ strongly agreed.

Appendix 1(d) shows the result of poor public services (PPS) as a justification for tax evasion. This component was broken down into taxpayers do not know what government does with the tax income; government not adequately protecting lives and property of its citizens; government health services generally being poor; roads being without maintenance for long, and biased government expenditure. Concerning taxpayers not knowing what the government does with tax income as a justification of tax evasion, $12 \%$ of the respondents strongly disagreed; $8 \%$ disagreed; $1 \%$ undecided; $38 \%$ agreed and $41 \%$ strongly agreed. With respect to the government not adequately protecting lives and property, $10 \%$ of the respondents strongly disagreed; $13 \%$ disagreed; $6 \%$ undecided; $34 \%$ agreed and 37\% strongly agreed. Regarding government health services generally being poor, $20 \%$ of the respondents strongly disagreed; $13 \%$ disagreed; $8 \%$ undecided; $26 \%$ agreed and 33\% strongly agreed. For roads being without maintenance for long, $10 \%$ of the respondents strongly disagreed; $19 \%$ disagreed; $4 \%$ not decided; $38 \%$ agreed, and 29\% strongly agreed. As concern biased government expenditure, $19 \%$ of the respondents strongly disagreed; $16 \%$ disagreed; $20 \%$ not decided; $23 \%$ agreed, and $22 \%$ strongly agreed.

Appendix 1(e) characterises the elements that constitute low income (LI) as a justification for tax evasion. The components of low income are the high fluctuation of business income; income being too low most of the time; low business sales; and cost of sales and/or cost of production being too high. Business income fluctuating a lot as a justification of tax evasion, $12 \%$ of the respondents strongly disagreed; $23 \%$ disagreed; $1 \%$ undecided; $35 \%$ agreed and $29 \%$ strongly agreed. With respect to income being too low most of the time, $18 \%$ of the respondents strongly disagreed; $19 \%$ disagreed; $5 \%$ undecided; $27 \%$ agreed and $31 \%$ strongly agreed. Regarding low business sales, $17 \%$ of the respondents strongly disagreed; $18 \%$ disagreed; $9 \%$ undecided; $32 \%$ agreed and $24 \%$ strongly agreed. As concern cost of production being high, $23 \%$ of the respondents strongly disagreed; $12 \%$ disagreed; $11 \%$ not decided; $30 \%$ agreed, and $24 \%$ strongly agreed.

Appendix 1(f) shows the result of tax evasion benefits outweighing the detection and penalty (EBODP) as a justification for tax evasion. The components are: more profit being made through evasion; easy settlement when caught, and penalty of evasion being easily paid. With respect to businesses making more profits through evasion as a justification of tax evasion, $20 \%$ of the respondents strongly disagreed; $13 \%$ disagreed; $14 \%$ undecided; $41 \%$ agreed and $12 \%$ strongly agreed. With respect to easy settlement when caught, $15 \%$ of the respondents strongly disagreed; $21 \%$ disagreed; $13 \%$ undecided; $24 \%$ agreed and $27 \%$ strongly agreed. As concern the fact that penalty for evasion can easily be paid as a justification for evasion, $12 \%$ of the respondents strongly disagreed; $17 \%$ disagreed; $9 \%$ not decided; $32 \%$ agreed, and 30\% strongly agreed.

Appendix 1(g) shows the result relating to tax ethics as perceived by the respondents. $5 \%$ of the respondents strongly disagreed that taxpayers have a good relationship with government; $6 \%$ disagreed; $2 \%$ undecided; $29 \%$ agreed and $58 \%$ strongly agreed. With respect to taxpayers trusting the state, $11 \%$ of the respondents strongly disagreed; $14 \%$ disagreed; $1 \%$ undecided; $35 \%$ agreed and 39\% strongly agreed. Regarding fairness of the tax system, $17 \%$ of the respondents strongly disagreed; $19 \%$ disagreed; $13 \%$ undecided; $23 \%$ agreed and $28 \%$ strongly agreed. As concern the transparency of the government, $13 \%$ of the respondents strongly disagreed; $20 \%$ disagreed; $14 \%$ not decided; $25 \%$ agreed, and 28\% strongly agreed. Looking at fairness in the democratic political system, $2 \%$ of the respondents strongly disagreed; $7 \%$ disagreed; $2 \%$ not decided; $29 \%$ agreed; and $60 \%$ strongly agreed. With regards to citizens' personal satisfaction with the democratic political system, $13 \%$ of the respondents strongly disagreed; $15 \%$ disagreed; $18 \%$ not decided; $34 \%$ agreed, and $20 \%$ strongly agreed. Looking at national pride and a higher level of education, $10 \%$ of the respondents strongly disagreed; $26 \%$ disagreed; $10 \%$ not decided; 
$25 \%$ agreed; and $29 \%$ strongly agreed.

Appendix 1(h) presents the taxpayers' perception of the judicial system. Items here were: justice and fairness in trials, corruption and lack of credibility, taxpayers' influence on government and politicians. Regarding the judicial system being just and fair in its trials, $32 \%$ of the respondents strongly disagreed; $23 \%$ disagreed; $20 \%$ undecided; $10 \%$ agreed and $15 \%$ strongly agreed. With respect to its being easily influenced by taxpayers, government and politicians, $26 \%$ of the respondents strongly disagreed; $14 \%$ disagreed; $1 \%$ undecided; $23 \%$ agreed and $36 \%$ strongly agreed. Regarding corruption and lack of credibility, $12 \%$ of the respondents strongly disagreed; $18 \%$ disagreed; $4 \%$ undecided; $37 \%$ agreed and $29 \%$ strongly agreed.

On the other hand, appendix 2 presents the percentage of income declared to tax authorities by the taxpayer. This variable captures the perception of tax evasion by the taxpayer. From the result, 3\% of the respondents declared their entire income to the tax authority; $11 \%$ declared from $80 \%$ less than $100 \%$ of their income to tax authority; $38 \%$ declared from $60 \%$ to less $80 \%$ of their income to tax authority; $39 \%$ declared from $40 \%$ to less $60 \%$ of their income to tax authority and $9 \%$ declared less than $40 \%$ of their income to tax authority. Thus the majority of the taxpayers only declare from $40 \%$ to less than $60 \%$ of their income to tax authority.

\section{Discussions of Results}

The regression results of the determinants of tax evasion estimated using the ordered logit estimation technique were presented in table 2 below. It is observed from the percentage of income declared to tax authority given in appendix 2 that, there were five (5) levels of tax payment that were considered. Consequently, there were four cut off points presented in the results. The coefficients on the table are logodds. In the interpretation of the coefficients, a negative value showed that individuals did not pay all their taxes, hence increased the likelihood of tax evasion.

From the result, the perception that taxes are high has a negative effect on the likelihood of tax evasion. The result specifically shows that a unit increase in the perception that taxes are high will reduce the probability of paying taxes by a log-odd of 0.6168 . Translating the coefficient into the odd ratio, the result means that when the perception that taxes are high increases by 1 unit, the likelihood of not paying taxes will increase by $46 \%$. This result is statistically significant at 5\% level of significance since the p-value of 0.039 is less than 5\%. It is supported by the findings in a study of the causes of tax evasion and corruption in the Indian income tax system, where Arora and Vanita (2010) disclosed that high tax rates constitute one of the main reasons why tax evasion thrives in India. This result further affirms the outcome of the study of the factors that influence tax evasion behaviour in Ghana by Ameyaw and Dzaka (2016), Tanzi (1983), and Allingham and Sandmo (1972), that high tax rates significantly provoke evasion.

\section{Table 2. Ordered logistic results on the determinants of tax evasion}

\begin{tabular}{|l|c|c|c|c|}
\hline \multicolumn{1}{|c|}{ Evasion } & Coefficient & Standard Error & $\mathrm{Z}$ & $\mathrm{P}>|\mathrm{z}|$ \\
\hline High taxes & $-0.616791^{* *}$ & 0.299442 & -2.06 & 0.039 \\
\hline Poor public services & -0.363396 & 0.381867 & -0.95 & 0.341 \\
\hline Income level & $0.684951^{* *}$ & 0.290868 & 2.35 & 0.019 \\
\hline Evasion benefits outweigh detection penalties & $-0.923323^{* *}$ & 0.467317 & -1.98 & 0.048 \\
\hline Complex and opaque tax & $-0.699828^{* *}$ & 0.325020 & -2.15 & 0.038 \\
\hline Inefficient and corrupt tax & $-0.277970^{*}$ & 0.169069 & -1.64 & 0.100 \\
\hline Perception of judicial system & $0.228317^{*}$ & 0.100868 & 2.26 & 0.025 \\
\hline Cut1 & 2.589063 & 1.987901 & & \\
\hline Cut2 & 4.80624 & 2.046254 & & \\
\hline Cut3 & 5.641973 & 2.075818 & & \\
\hline Cut4 & 9.324384 & 2.475175 & & \\
\hline Number of obs & 318 & & & \\
\hline LR chi ${ }^{2}$ (8) & 17.56 & Prob $>$ chi2 & $=$ & 0.0247 \\
\hline Pseudo R ${ }^{2}$ & 0.1513 & & & \\
\hline
\end{tabular}

$* * *$ Significant at $1 \%$, ** significant at $5 \%$ and $*$ significant at $10 \%$.

Source: Authors' computation

Poor public services also have a negative effect on tax evasion. Specifically, from the result, an increase in the perception that public services are poor by a unit reduces the likelihood of paying the complete amount of taxes by a log-odd of 0.3634 . Translating the coefficient into percentages, the result will specifically mean that an increase in the perception of poor public services reduces the probability of paying taxes by some $30 \%$. However, this result is statistically insignificant since the $p$-value of 0.341 is greater than $10 \%$. This result confirms the assertion by Martinez-Vazquez and (McNab, 2003; Pashev, 2005; EverestPhillips, 2008; Brautigam et al., 2008) that every taxpayer expects a fair service from the government for taxes paid.

The more the taxpayer is deprived of basic services such as potable water, electricity, health, security, and good road networks, the level of noncompliance increases. This result validates the findings of Drogalas et al. 
(2018) that tax evasion increases when taxpayers believe that public money is not efficiently allocated to the citizens. The inefficient allocation of public money in Cameroon could be linked to the fact that every year more money is allocated for investment projects in some regions of the country at the expense of others.

The income level is positive, thus an increase in income level increases the probability of paying taxes thus reduces the likelihood of tax evasion. Specifically, from the result, a unit increase in income will increase the logodd of not evading taxes by 0.6850 . Translating the coefficient into odd ratio, the result specifically shows that when income level increases, it becomes about $98 \%$ more likely that individuals will not evade taxes. This result is statistically significant at 5\% level of significance since the p-value of 0.019 is less than $5 \%$. Where low income leads to noncompliance, a reduction of tax rates could significantly improve compliance. Such a remedy supports the findings of Wadhwa and Pal (2012).

In terms of the perception that evasion benefits outweigh detection and penalty, the coefficient is negative showing that individuals will evade taxes once they perceived that the benefits of evasion are more than the cost of detection and penalty. The result shows that the likelihood of paying taxes reduces by the log-odd of 0.9233 . This result is statistically significant at $5 \%$ level of significance since the p-value of 0.048 is less than $5 \%$. This result complies with the submission of Dalu, Maposa, Pabwaungana, and Dalu (2012) that taxpayers aim at minimising their financial position by evading taxes as long as the benefits from delinquency outweigh the risk of detection and penalty. A solution to this challenge may be in Fishlow and Friedman (1994) posit that higher penalties act as a deterrent and help to improve tax compliance. However, the application of more severe penalties can serve as a panacea as long as the tax evasions are detected. This will require the tax authorities to be efficient enough to detect the level of evasion. It will also require them to be morally upright not to interfere with the degree of evasion by falling prey to corruption and bribery.

Complex and opaque tax laws also encourage individuals to evade taxes as shown by the negative coefficient. The result shows that an increase in the perception that the tax laws are complex and opaque will increase the logodd of not paying taxes by 0.6998 . In terms of odd ratios, there is about $50 \%$ less likelihood of paying taxes if the tax laws are perceived to be complex and opaque. This result is statistically significant at $5 \%$ level of significance since the p-value of 0.038 is less than 5\%. Arora and Vanita (2010) proposed as a solution a simplification of tax regulations and laws. Simplification of tax laws broadens tax education, hence tax compliance.

Arora and Vanita (2010) disclosed that high tax rates, social acceptance of tax evasion, poor tax evasion detection mechanisms, low tax ethics, and corruption, constitute the main reasons why evasion thrives in India. The study furthermore revealed that the income tax authorities apart from being morally bankrupt wielded excessive discretionary powers that led to corruption. As a remedy, they proposed the justification of tax rates, simplification of tax regulations and laws. They also encouraged an extensive application of the tax system where tax is deducted at source, and proper processing and dissemination of tax information, in a bid to step up tax compliance.

Inefficient and corrupt tax inspectors have a negative effect on the ability to pay taxes. In other words, when taxpayers perceive that the tax officials are inefficient and corrupt, the likelihood of evading taxes increases by a log-odd of 0.2780 . Translating the coefficient into percentages, the result will specifically mean that when individuals perceive that tax inspectors are inefficient and corrupt, the likelihood not to pay all the taxes increases by about $32 \%$. This result is statistically significant at $10 \%$ level of significance since the p-value of 0.100 is not greater than 10\%. This result supports the disclosure by Arora and Vanita (2010) that poor tax evasion detection mechanisms upsurge tax evasion. It also agrees with Wadhwa and Pal (2012) who carried out forensic accounting and fraud examination in India to opine that corrupt and inefficient tax authorities are the principal causes of tax evasion.

The judicial system is found to have a positive influence on the likelihood to pay taxes fully. That is, it decreases the likelihood of evading taxes. From the results, if taxpayers perceived that the judicial system is fair and just, they are encouraged to pay their taxes. The results specifically show that the log odds of not evading taxes will increase by 0.22832 . Translating the coefficient into odd ratio, the result specifically shows that when the perception of judiciary fairness increases, the likelihood of individuals not evading taxes increases by $25.6 \%$. This result is statistically significant at 5\% level of significance and agrees with the findings of Vythelingum, Soondram, and Jugurnath, (2017) among Mauritian taxpayers that, tax compliance increases when the public has faith in the tax and legal systems being stable, fair and transparent, and seen to effectively fight against corruption. The judiciary in Cameroon should be able to make politicians accountable for their decisions and use of public money, in order to rebuild trust between the government and its taxpayers.

\section{Policy Implications, Recommendations and Conclusion}

The findings generated in this study of tax evasion in Cameroon reveal that high taxes, low-income level of taxpayers, evasion benefits outweighing detection and penalty, inefficient and corrupt tax officials, complex and opaque tax system, poor perception of the judicial system, and poor public services offered by the government are the fundamental causes of tax evasion in Cameroon. 
To overcome the challenges of tax evasion, the Cameroon government should reduce and conscientiously justify its tax rates. The tax laws should be simplified and taxpayers or economic operators properly schooled through episodic seminars.

The income level of taxpayers can be improved if the government ensures a more conducive business environment with enhanced availability and quality of basic amenities such as security, electricity supply, internet, water, health, and transportation network.

Vis-à-vis tax evasion benefits outweighing tax detection and penalty, tax evasion penalties should be raised in order to discourage the practice. However, for this to be effective, the tax evasion itself must be uncovered, and not negotiated by unscrupulous tax authorities. In this regard, corrupt and inefficient tax inspectors must be identified and dealt with accordingly in order to forestall contamination of the few morally upright tax inspectors. Tax auditors and tax information processing officers should be knowledgeable, sincere, and patriotic.

The judiciary in Cameroon is poorly perceived by taxpayers and this leads to tax noncompliance. This can be reversed if the judicial system gains independence and starts showing proof of fairness and transparency in handling tax-related matters, fighting against corrupt practices by both tax inspectors and taxpayers, and cause politicians to be accountable for their decisions and use of public money.

Tax ethics should be introduced in schools so as to build a moral obligation in citizens to be tax compliant, tax authorities to be assiduous and honest, and politicians to be transparent and accountable.

\section{References}

Adam, S. (1950). An Inquiry into the Nature and Causes of the Wealth of Nations, ed. Edwin Cannan, Retrieved January 2019

https://www.google.com/search?q=Adam+Smith\%2C+An+inquiry+into+the+nature + causes + of + the + Wealt $\mathrm{h}+\mathrm{of}+$ Nations

Alm, J. A. (1991). Perspective on the experimental analysis of taxpayer reporting. The Accounting Review Vol. 66, No. 3.

Anyanfo, A.M.O. (1996). Public Finance in a Developing Economy: The Nigerian Case, Enugu: Department of Banking and Finance, University of Nigeria, Enugu

Arora, R. S. and Vaneeta, R. (2010). Tax evasion and corruption in the Indian Income Tax System: causes and remedies, Indian journal of Finance, Vol. 4, pp. 30-36

Brautigam, Deborah, Odd-Helge Fjeldstad and Mick Moore (eds.) (2008), Taxation and state-building developing countries. Capacity and consent, Cambridge University Press.

Campus.Ameyaw, B. and Dzaka, D. (2016) Determinants of Tax Evasion: Empirical Evidence from Ghana. Modern Economy, 7, 1653-1664. http://dx.doi.org/10.4236/me.2016

Carnahan, M. (2015). Taxation Challenges in Developing Countries. Asia \& the Pacific Policy Studies, Vol. 2 , No. 1, pp. 169-182 doi: 10.1002/app5.70

Christians, A. (2017). Distinguishing tax avoidance and evasion: why and how, Journal of Tax Administration Vol $3: 2$

Dalu, T., Maposa, V.G., Pabwaungana, S. and Dalu, T. (2012) 'The impact of tax evasion and avoidance on the economy: a case of Harare, Zimbabwe', African J. Economic and Sustainable Development, Vol. 1, No. 3, pp.284-296.

Devarajappa, S. (2017) Tax evasion in India: A study of its impact on revenue of the government, EPRA International Journal of Economic and Business Review, Vol. 5, No. 9.

Dictionary of Accounting (2010). Tax avoidance, Oxford University Press, $4 e$

Drogalas, G., Anagnostopoulou, E., Pazarskis, M. and Petkopoulos, D. (2018) Tax Ethics and Tax Evasion, Evidence from Greece. Theoretical Economics Letters 8, 1018-1027. Retrieved January 2019 from https://doi.org/10.4236/tel.2018.85070

Everest-Phillips, Max (2008), Business tax as state-building in developing countries: applying governance principles in private sector development, International Journal of Regulation and Governance 8(2), pp. 123154

Fishlow, A. and J. Friedman (1994), Tax evasion, inflation and stabilization, Journal of Development Economics, Vol. 43, No. 1, pp. 105-123.

Forstater, M., 2018. "Tax and Development: New Frontiers of Research and Action" CGD Policy Paper. Washington, DC: Center for Global Development. https://www.cgdev.org/publication/taxand-developmentnew-frontiers-research-and-action

Franzoni, L. (2000). Tax evasion and tax compliance. Encyclopedia of Law and Economic, Vol.VI, In: Boukaertm B., De Geest, G. (Eds.), The Economic and Public Tax Law, Edward Elgar, Cheltenham

Elliffe, G. (2011). The thickness of a prison wall - When does tax avoidance become a criminal offence? New Zealand business law quarterly, Vol. 17, No. 4, pp 441-466

Gooch, G. and Williams, M. (2015). A Dictionary of law enforcement, retrieved January $2019 \quad$ from 
http://www.oxfordreference.com/abstract/10.1093/acref/978019175825

Vito Tanzi and Howell Zee (2001). Tax Policy for Developing Countries, International Monetary Fund Publications. Retrieved June 2019 from https://www.imf.org/external/pubs/ft/issues/issues27/ Jhingan, M.L. (2004). Money, Banking, International Trade and Public Finance, New Delhi: Vrinda Publications

Kalpana, V., (2016). Tax evasion - a major threat to economic development and growth - causes and remedies. International journal of scientific engineering and research (IJSER), Vol. 4, No. 5.

Martinez-Vazquez, J. and McNab R. (2003). Fiscal Decentralization and Economic Growth, World Development, 2003, vol. 31, issue 9, 1597-1616

McGee, R.W. and Rossi, M.J. (2006). The Ethics of Tax Evasion: A Survey of Law and Business Students in Argentina. Proceedings of 6th Annual International Business Research Conference, Jacksonville, Florida.

Merriam Webster Dictionary, https://www.merriam webster.com/dictionary/benefit $\% 20$ theory $\% 20$ of $\% 20$ taxation

MINFI, (2018). Instructions relating to the execution of finance laws, the monitoring and control of the execution of the budget of the State, public corporations and public establishments, regional and local authorities and other subsidised bodies, for the 2018 financial year. Retrieved June 2018 from https://www.cabrisbo.org/.../cameroon_2018_formulation internal_treasury_guidelin...

Ngoran, S. D. (2014). Socio-environmental impacts of sprawl on the coastline of Douala: Options for integrated coastal management, Anchor Academic Publishing

Olsen, Kang, and Kirchler, (2012). Tax Psychology. In: Lewis, A., Ed., The Cambridge Handbook of Psychology and Economic Behaviour, Cambridge University Press, Cambridge

Organization of Economic Cooperation and Development-OECD (2017), Glossary of Tax Terms. Retrieved December 2018 from http://www.oecd.org/ctp/glossaryoftaxterms.htm

Pashev, K. (2005). Tax Compliance of Small Business in Transition Economies: Lessons from Bulgaria. Working paper 05-10. Andrew Young School of Policy Studies. Atlanta Georgia.

Roth, J. A., Scholz, J. T., and Witte, A. D., (1989). Taxpayer Compliance: An Agenda for Research. Philadelphia: University of Pennsylvania Press

Tanzi, V. (1983) The Underground Economy in the United States. Annual Estimates; 1930-1980. International Monetary Fund Staff Papers, 30, 283-305.

Tanzi, V. and Zee, H. (2001). Tax policy for developing countries. Retrieved February 2018 from https://www.imf.org/external/pubs/ft/issues/issues27

Torgler, B. and Schneider, F. (2009). The Impact of Tax Morale and Institutional Quality on the Shadow Economy. Journal of Economic Psychology, 30, 228-245. https://doi.org/10.1016/j.joep.2008.08.004

Vythelingum, P., Soondram, H. and Jugurnath, B. (2017) An Assessment of Tax Morale among Mauritian Taxpayers. Journal of Accounting and Taxation, 9, 1- $\quad$ 10. https://doi.org/10.5897/JAT2016.0224

Wadhwa, L. and Pal, V. (2012). Forensic accounting and fraud examination in India, International Journal of Applied Engineering Research, Vol. 7, No. 11

WHO (2019). Cameroon, Retrieved from March 2019 from https://www.who.int/countries/cmr/en/

Appendix 1: Determinants of tax evasion

\begin{tabular}{|c|c|c|c|c|c|c|}
\hline \multicolumn{7}{|l|}{ (A) High tax rates (HTR) } \\
\hline Items & $\begin{array}{l}\text { Strongly } \\
\text { disagree }\end{array}$ & Disagree & $\begin{array}{l}\text { Not } \\
\text { decided }\end{array}$ & Agree & $\begin{array}{l}\text { Strongly } \\
\text { agree }\end{array}$ & Total \\
\hline \multirow{2}{*}{$\begin{array}{l}\text { a) They don't have enough money to pay } \\
\text { all the tax there is. }\end{array}$} & 45 & 70 & 25 & 102 & 109 & \multirow[t]{2}{*}{351} \\
\hline & $13 \%$ & $20 \%$ & $7 \%$ & $29 \%$ & $31 \%$ & \\
\hline \multirow{2}{*}{$\begin{array}{l}\text { b) The tax rate is too high compared to the } \\
\text { income made }\end{array}$} & 17 & 39 & 21 & 144 & 130 & \multirow[t]{2}{*}{351} \\
\hline & $5 \%$ & $11 \%$ & $6 \%$ & $41 \%$ & $37 \%$ & \\
\hline \multirow[t]{2}{*}{ c) Many taxes to pay } & 59 & 28 & 38 & 73 & 150 & \multirow[t]{2}{*}{348} \\
\hline & $17 \%$ & $8 \%$ & $11 \%$ & $21 \%$ & $43 \%$ & \\
\hline
\end{tabular}




\section{(B) Poor public services (PPS)}

\begin{tabular}{|c|c|c|c|c|c|c|}
\hline Items & $\begin{array}{l}\text { Strongly } \\
\text { disagree }\end{array}$ & Disagree & $\begin{array}{l}\text { Not } \\
\text { decided }\end{array}$ & Agree & $\begin{array}{l}\text { Strongly } \\
\text { agree }\end{array}$ & Total \\
\hline $\begin{array}{l}\text { a) They don't know what government } \\
\text { does with the tax income }\end{array}$ & $\begin{array}{l}42 \\
12 \% \\
\end{array}$ & $\begin{array}{l}28 \\
8 \%\end{array}$ & $\begin{array}{l}4 \\
1 \% \\
\end{array}$ & $\begin{array}{l}133 \\
38 \% \\
\end{array}$ & $\begin{array}{l}143 \\
41 \% \\
\end{array}$ & 350 \\
\hline $\begin{array}{l}\text { b) The government does not adequately } \\
\text { protect lives and property }\end{array}$ & $\begin{array}{ll}35 \\
10 \% \\
\end{array}$ & $\begin{array}{ll}46 \\
13 \% \\
\end{array}$ & $\begin{array}{l}21 \\
6 \% \\
\end{array}$ & $\begin{array}{l}119 \\
34 \% \\
\end{array}$ & $\begin{array}{l}129 \\
37 \% \\
\end{array}$ & 350 \\
\hline $\begin{array}{l}\text { c) Government health services are } \\
\text { generally poor }\end{array}$ & $\begin{array}{ll}70 \\
20 \%\end{array}$ & $\begin{array}{ll}46 \\
13 \%\end{array}$ & $\begin{array}{l}28 \\
8 \%\end{array}$ & $\begin{array}{ll}91 \\
26 \%\end{array}$ & $\begin{array}{ll}116 \\
33 \%\end{array}$ & 351 \\
\hline d) Roads go for long without maintenance & $\begin{array}{ll}35 \\
10 \% \\
\end{array}$ & $\begin{array}{ll}67 \\
19 \% \\
\end{array}$ & $\begin{array}{l}14 \\
4 \% \\
\end{array}$ & $\begin{array}{l}133 \\
38 \% \\
\end{array}$ & $\begin{array}{ll}101 \\
29 \%\end{array}$ & 350 \\
\hline e) Government expenditure is bias & $\begin{array}{ll}66 \\
19 \% \\
\end{array}$ & $\begin{array}{ll}56 \\
16 \% \\
\end{array}$ & $\begin{array}{ll}70 \\
20 \% \\
\end{array}$ & $\begin{array}{ll}80 \\
23 \% \\
\end{array}$ & $\begin{array}{ll}77 \\
22 \% \\
\end{array}$ & 349 \\
\hline \multicolumn{7}{|l|}{ (C) Low income (LI) } \\
\hline Items & $\begin{array}{l}\text { Strongly } \\
\text { disagree }\end{array}$ & Disagree & $\begin{array}{l}\text { Not } \\
\text { decided }\end{array}$ & Agree & $\begin{array}{l}\text { Strongly } \\
\text { agree }\end{array}$ & Total \\
\hline a) Business income fluctuates a lot & $\begin{array}{ll}42 \\
12 \% \\
\end{array}$ & $\begin{array}{l}80 \\
23 \%\end{array}$ & $\begin{array}{ll}3 \\
1 \% \\
\end{array}$ & $\begin{array}{l}121 \\
35 \%\end{array}$ & $\begin{array}{l}101 \\
29 \%\end{array}$ & 347 \\
\hline b) Most of the time the income is too low & $\begin{array}{ll}63 \\
18 \% \\
\end{array}$ & $\begin{array}{ll}66 \\
19 \% \\
\end{array}$ & $\begin{array}{l}17 \\
5 \%\end{array}$ & $\begin{array}{l}94 \\
27 \% \\
\end{array}$ & $\begin{array}{l}108 \\
31 \%\end{array}$ & 348 \\
\hline c) Business sales are low & $\begin{array}{ll}60 \\
17 \% \\
\end{array}$ & $\begin{array}{ll}63 \\
18 \% \\
\end{array}$ & $\begin{array}{l}32 \\
9 \% \\
\end{array}$ & $\begin{array}{l}112 \\
32 \% \\
\end{array}$ & $\begin{array}{ll}84 \\
24 \% \\
\end{array}$ & 351 \\
\hline $\begin{array}{l}\text { d) Cost of sales and/or cost of production } \\
\text { is high }\end{array}$ & $\begin{array}{l}81 \\
23 \% \\
\end{array}$ & $\begin{array}{l}42 \\
12 \% \\
\end{array}$ & $\begin{array}{ll}39 \\
11 \% \\
\end{array}$ & $\begin{array}{l}105 \\
30 \%\end{array}$ & $\begin{array}{l}84 \\
24 \% \\
\end{array}$ & 351 \\
\hline \multicolumn{7}{|c|}{ (D) Evasion benefits outweigh detection and penalties (EBODP) } \\
\hline $\begin{array}{l}\text { a) In this way our business makes more } \\
\text { profit }\end{array}$ & $\begin{array}{l}\text { disagree } \\
70 \\
20 \% \\
\end{array}$ & $\begin{array}{l}46 \\
13 \% \\
\end{array}$ & $\begin{array}{l}\text { decided } \\
49 \\
14 \% \\
\end{array}$ & $\begin{array}{l}143 \\
41 \% \\
\end{array}$ & $\begin{array}{l}\text { agree } \\
22 \\
12 \% \\
\end{array}$ & 350 \\
\hline $\begin{array}{l}\text { b) Even when caught it can easily be } \\
\text { settled }\end{array}$ & $\begin{array}{ll}52 \\
15 \% \\
\end{array}$ & $\begin{array}{ll}73 \\
21 \% \\
\end{array}$ & $\begin{array}{ll}46 \\
13 \%\end{array}$ & $\begin{array}{ll}84 \\
24 \% \\
\end{array}$ & $\begin{array}{l}95 \\
27 \% \\
\end{array}$ & 350 \\
\hline c) The penalty for this can easily by paid & $\begin{array}{ll}42 \\
12 \%\end{array}$ & $\begin{array}{ll}60 \\
17 \%\end{array}$ & $\begin{array}{l}32 \\
9 \%\end{array}$ & $\begin{array}{l}112 \\
32 \%\end{array}$ & $\begin{array}{l}105 \\
30 \%\end{array}$ & 351 \\
\hline \multicolumn{7}{|c|}{ (E) Complex and opaque tax laws (COTL) } \\
\hline Items & $\begin{array}{l}\text { Strongly } \\
\text { disagree }\end{array}$ & Disagree & $\begin{array}{l}\text { Not } \\
\text { decided }\end{array}$ & Agree & $\begin{array}{l}\text { Strongly } \\
\text { agree }\end{array}$ & Total \\
\hline a) The tax laws are not understood & $\begin{array}{l}32 \\
9 \% \\
\end{array}$ & $\begin{array}{l}42 \\
12 \%\end{array}$ & $\begin{array}{l}45 \\
13 \% \\
\end{array}$ & $\begin{array}{l}112 \\
32 \%\end{array}$ & $\begin{array}{l}119 \\
34 \% \\
\end{array}$ & 350 \\
\hline $\begin{array}{l}\text { b) The tax regulations are too many and } \\
\text { confusing }\end{array}$ & $\begin{array}{l}35 \\
10 \% \\
\end{array}$ & $\begin{array}{l}46 \\
13 \% \\
\end{array}$ & $\begin{array}{l}28 \\
8 \%\end{array}$ & $\begin{array}{l}116 \\
33 \%\end{array}$ & $\begin{array}{l}126 \\
36 \%\end{array}$ & 351 \\
\hline $\begin{array}{l}\text { c) The calculation is not easy to } \\
\text { understand }\end{array}$ & $\begin{array}{l}14 \\
4 \%\end{array}$ & $\begin{array}{l}21 \\
6 \%\end{array}$ & $\begin{array}{l}4 \\
1 \%\end{array}$ & $\begin{array}{l}77 \\
22 \%\end{array}$ & $\begin{array}{l}235 \\
67 \%\end{array}$ & 351 \\
\hline $\begin{array}{l}\text { d) Copies of the tax code/law are available } \\
\text { only to the tax inspectors }\end{array}$ & $\begin{array}{ll}4 \\
1 \% \\
\end{array}$ & $\begin{array}{l}14 \\
4 \% \\
\end{array}$ & $\begin{array}{l}42 \\
12 \% \\
\end{array}$ & $\begin{array}{ll}88 \\
25 \% \\
\end{array}$ & $\begin{array}{l}203 \\
58 \%\end{array}$ & 351 \\
\hline \multicolumn{7}{|c|}{ (F) Inefficient and Corrupt Tax Inspectors (ICTI) } \\
\hline Items & $\begin{array}{l}\text { Strongly } \\
\text { disagree }\end{array}$ & Disagree & $\begin{array}{l}\text { Not } \\
\text { decided }\end{array}$ & Agree & $\begin{array}{l}\text { Strongly } \\
\text { agree }\end{array}$ & Total \\
\hline a) They don't trust the tax inspectors & $\begin{array}{l}73 \\
21 \% \\
\end{array}$ & $\begin{array}{ll}66 \\
19 \% \\
\end{array}$ & $\begin{array}{l}31 \\
9 \% \\
\end{array}$ & $\begin{array}{ll}77 \\
22 \% \\
\end{array}$ & $\begin{array}{l}101 \\
29 \% \\
\end{array}$ & 348 \\
\hline b) They can easily bribe out their way & $\begin{array}{ll}56 \\
16 \% \\
\end{array}$ & $\begin{array}{ll}70 \\
20 \% \\
\end{array}$ & $\begin{array}{l}83 \\
24 \% \\
\end{array}$ & $\begin{array}{ll}66 \\
19 \% \\
\end{array}$ & $\begin{array}{ll}73 \\
21 \% \\
\end{array}$ & 348 \\
\hline $\begin{array}{l}\text { c) They can easily negotiate with tax } \\
\text { agents }\end{array}$ & $\begin{array}{ll}60 \\
17 \%\end{array}$ & $\begin{array}{ll}77 \\
22 \% \\
\end{array}$ & $\begin{array}{ll}17 \\
5 \% \\
\end{array}$ & $\begin{array}{ll}84 \\
24 \% \\
\end{array}$ & $\begin{array}{ll}112 \\
32 \%\end{array}$ & 350 \\
\hline $\begin{array}{l}\text { d) Tax auditors/inspectors don't question } \\
\text { amount declared }\end{array}$ & $\begin{array}{l}112 \\
32 \%\end{array}$ & $\begin{array}{l}70 \\
20 \%\end{array}$ & $\begin{array}{ll}46 \\
13 \% \\
\end{array}$ & $\begin{array}{ll}60 \\
17 \%\end{array}$ & $\begin{array}{l}63 \\
18 \%\end{array}$ & 351 \\
\hline e) Tax agents are kind and accept pleas & $\begin{array}{l}70 \\
20 \%\end{array}$ & $\begin{array}{l}52 \\
15 \% \\
\end{array}$ & $\begin{array}{l}88 \\
25 \%\end{array}$ & $\begin{array}{l}67 \\
19 \% \\
\end{array}$ & $\begin{array}{l}74 \\
21 \%\end{array}$ & 351 \\
\hline
\end{tabular}




\section{(G) Tax payer perception of the judicial system}

\begin{tabular}{|c|c|c|c|c|c|c|}
\hline Items & $\begin{array}{l}\text { Strongly } \\
\text { disagree }\end{array}$ & Disagree & $\begin{array}{l}\text { Not } \\
\text { decided }\end{array}$ & Agree & $\begin{array}{l}\text { Strongly } \\
\text { agree }\end{array}$ & Total \\
\hline \multirow{2}{*}{ a) Just and fair in its trials } & 112 & 81 & 70 & 35 & 53 & \multirow[t]{2}{*}{351} \\
\hline & $32 \%$ & $23 \%$ & $20 \%$ & $10 \%$ & $15 \%$ & \\
\hline \multirow{2}{*}{$\begin{array}{l}\text { b) Easily influenced by tax payers, } \\
\text { government and politicians }\end{array}$} & 91 & 49 & 4 & 81 & 126 & \multirow[t]{2}{*}{351} \\
\hline & $26 \%$ & $14 \%$ & $1 \%$ & $23 \%$ & $36 \%$ & \\
\hline \multirow[t]{2}{*}{ c) Corrupt and lacks credibility } & 42 & 63 & 14 & 130 & 102 & \multirow[t]{2}{*}{351} \\
\hline & $12 \%$ & $18 \%$ & $4 \%$ & $37 \%$ & $29 \%$ & \\
\hline
\end{tabular}

\section{Source: Author's computation}

\section{Appendix 2: Percentage of income declared to tax authority} Income declared to tax authority

\begin{tabular}{lll}
\hline a) $100 \%$ & 11 & $3 \%$ \\
\hline b) $[80 \%$ and $100 \%[$ & 39 & $11 \%$ \\
\hline c) $[60 \%$ and $80 \%[$ & 133 & $38 \%$ \\
\hline d) $[40 \%$ and $60 \%[$ & 137 & $39 \%$ \\
\hline e) Less than $40 \%$ & 31 & $9 \%$ \\
\hline
\end{tabular}

Source: Author's computation 